\title{
sciendo
}

\section{PREVALENCE OF PORCINE CIRCOVIRUS TYPE 2 IN NATURALLY INFECTED PIGS IN ABEOKUTA, NIGERIA}

\author{
Eleazar, A. N. ${ }^{1}$, Takeet, M. I. ${ }^{2}$, Sonibare, A. O. ${ }^{1}$, Olufemi, F..$^{2}{ }^{2}$, Otesile, E. B. ${ }^{1}$ \\ ${ }^{1}$ Department of Veterinary Medicine and Surgery \\ ${ }^{2}$ Department of Veterinary Microbiology and Parasitology, College of Veterinary Medicine \\ Federal University of Agriculture Abeokuta, Ogun State \\ Nigeria
}

amelia.eleazar@yahoo.com

\section{ABSTRACT}

Porcine circovirus type 2 (PCV2) associated diseases are a group of emerging devastating pig diseases worldwide. Due to a dearth of information on the virus in Nigeria, this study was carried out on 12 farms in Abeokuta Ogun State, Nigeria. Key production problems were identified through a questionnaire survey and direct field observations. The prevalence of the PCV2 was determined by the Polymerase Chain Reaction (PCR); 207 sera of pigs were obtained from the farms, DNAs extracted and amplified by the PCR. Based on gel results, the prevalence of PCV2 types were recorded and the effects of age, sex and geographic area determined. The observed production problems (and the percentage of farms suffering from such problems) were: runting (91.7\%), high piglet mortality $(83.3 \%)$, late term abortion (50\%), stillbirth (50\%) and anoestrous (41.7\%). The overall prevalence of $8.7 \%$ of the PCV2 viral DNA was obtained. A single infection of PCV2b and PCV2a accounted for a prevalence of $5.3 \%$ and $2.4 \%$, respectively, while a concurrent infection of both was found in only $1 \%$ of the pigs. The prevalence of PCV2 was not significantly $(P>0.05)$ influenced by age or sex; with the rates in adults, growers and piglets being 9.9\%, $8.1 \%$ and $8.1 \%$, respectively, while in males and females, the rates were $9.4 \%$ and $9.0 \%$, respectively. The prevalence of PCV2 in high-density areas (13.2\%) was significantly $(\mathrm{P}<0.05)$ higher than in low-density areas $(4.0 \%)$. It was concluded that PCV2a and PCV2b were present in pigs in Abeokuta, Nigeria and PCV2b was more prevalent. It was recommended that large-scale epidemiological studies covering all geographical regions be carried out with sequencing and phylogenetic analysis to characterize the PCV2 genotypes present in Nigeria.

Key words: Nigeria; PCR; PCV2 viral DNA; pig; Porcine Circovirus type 2; prevalence

\section{INTRODUCTION}

Porcine circovirus type 2 (PCV2) is the causative agent of porcine circovirus associated diseases (PCVADs), an 
emerging disease complex devastating the pig industry worldwide. It consists of non-enveloped viruses that belong to the genus Circovirus, family Circoviridae. They contain a circular, single-stranded DNA genome of approximately $1.76 \mathrm{~kb}[24,27]$. Porcine circovirus type 2 and PCVADs are present on all continents and have been reported in many countries worldwide [4]. PCV2 persists as a subclinical infection in most commercial pig herds [33]. Both asymptomatic and diseased pigs shed virus or viral DNA in excretions and secretions [26], contaminating the premises, with the most susceptible being post-weaned pigs. The virus is stable and persists in the environment for prolonged periods of time, resulting in the exposure of young piglets. The mode of infection is widely believed to be through the oro-nasal route [34].

The group of diseases associated with PCV2 include: Post-weaning Multi-systemic Wasting Syndrome (PMWS), a multifactorial disease that usually appears in weaned pigs between 7 and 16 weeks of age [35]; Porcine Dermatitis and Nephropathy Syndrome (PDNS) is commonly seen in pigs that are 12-14 weeks of age [20]; Porcine Respiratory Disease Complex affects pigs from 8 to 26 weeks of age [17]; enteritis with PCV2 involvement often affects animals between 8 and 16 weeks of age [22]; reproductive failure affects mostly first parity gilts [38]; while congenital tremors affect newborn piglets [19].

Control and prevention strategies are two folds: improved management and biosecurity practices, and vaccination. The major goals of improved management and biosecurity practices include minimizing pig-to-pig contact, ideal biosecurity, improved hygiene and nutrition $[25,15]$. Direct pig-to-pig contact has been identified as a potential means of viral spread in a herd [37]. Establishing solid partitions between pens and adopting all-in-allout systems across the farm are recommended to reduce the pig-to-pig contacts [37]. Using only semen or boars of known health status for artificial insemination (AI) and breeding, prevents vertical transmission of the virus. The quarantine of newly purchased pigs and minimizing visitors to a facility helps to prevent the introduction of new infections. Thorough cleaning and disinfection procedures using an effective disinfectant such as potassium peroxomonosulphate, sodium hypochlorite, and sodium hydroxide [22], in addition to other hygiene measures including regular changing of boots and clothes, prompt removal of sick and dead pigs, proper disposal of dead pigs have been recommended to curb the spread of infection within herds/farms [37].

The prevalence of PCV2 viral antigen (or DNA) recorded in different countries varied widely, including: $23 \%$ in Japan, $8 \%$ in Korea, $35 \%$ in the UK, $10 \%$ in the USA, and $50 \%$ in Taiwan [5]. In the sub-Saharan African regions, the virus has been detected and the disease reported only in three countries; South Africa [1, 12], Uganda [21, 28, 39] and Mozambique [23]. The prevalence of PCV2 DNA recorded also varied widely in these three countries, including: $15.93 \%$ in South Africa [2], $77 \%$ and $25 \%$ in Uganda $[21,39]$, and $54 \%$ in Mozambique, respectively [23].

PCV2 strains have been classified into four main genotypes (PCV2a, PCV2b, PCV2c, and PCV2d) based upon the phylogenetic analyses performed with their full genomes and ORF2 sequences [14, 40]. A fifth genotype, PCV2e has also been identified in Mexico and USA [16], all of which have neither been detected nor identified in Nigeria, although anti-PCV2 antibodies have been detected in pig sera at a prevalence of $1.4 \%$ [3].

There is insufficient data on the prevalence and genotypes of PCV2 in the sub-Sahara African regions [1]. Particularly, there is a dearth of information on PCV2 in Nigeria and not much work has been done to detect its presence in the country. In this study, the prevalence of PCV2 was determined by the use of the Polymerase Chain Reaction (PCR).

\section{MATERIALS AND METHODS}

\section{Study area, samples, data collection and the study animals}

Targeted surveillance was accomplished in 12 selected pig farms in Abeokuta and environs, by multi stage simple random sampling. Abeokuta is positioned at $7^{\circ} 9^{\prime} 39^{\prime} \mathrm{N}$ and $3^{\circ} 20^{\prime} 54^{\prime} \mathrm{E}$ on the Ogun River. The four local government areas (LGAs) are Abeokuta South, Abeokuta North, Odeda and Obafemi-Owode. Abeokuta South LGA has a human population of 250,278 and an area of $71 \mathrm{~km}^{2}$, Abeokuta North LGA has a population of 201,329 and an area of $808 \mathrm{~km}^{2}$, Obafemi-Owode LGA has a population of 228,851 and an area of $1,410 \mathrm{~km}^{2}$ while Odeda LGA has a population of 109,449 and an area of $1,560 \mathrm{~km}^{2}$ [6].

A total of 207 blood samples were randomly collected from pigs with different age groups, irrespective of their health status. The pigs sampled were of mixed breeds (Nigerian indigenous breed, Large White, Duroc, Landrace, 
Camborough) and were intensively managed. The age of the pigs sampled ranged from a day old to 24 months and were categorized according to the following production groups: $0-3$ months (piglets), 3-6 months (growers), and over six months (adults/breeders). The health status of each pig was recorded as sick or apparently healthy, based on the presence or absence of their clinical abnormalities. The clinical data were obtained by interviewing the farm owner, from farm records and/or by direct observation of the pigs and the farm environment. The sick pigs were physically examined and the clinical parameters noted. About $3 \mathrm{ml}$ of blood was collected via the anterior vena cava. The serum was harvested by allowing the blood to clot undisturbed at room temperature. It was centrifuged at $1000 \mathrm{~g}$ for 10 minutes. The supernatant serum was pipetted and transferred into Eppendorf tubes and stored at $-20^{\circ} \mathrm{C}$ until used later.

\section{Deoxyribonucleic acid (DNA) extraction}

Deoxyribonucleic acid was extracted from the serum using Quick-gDNATMMiniPrep (Zymo Research Corporation, Irvine, CA 92614, USA) as described by the manufacturer. Briefly, $200 \mu \mathrm{l}$ of genomic lysis buffer was added to $50 \mu \mathrm{l}$ of serum in a sterile $1.5 \mathrm{ml}$ Eppendorf tube, thoroughly mixed by vortexing for $4-6$ seconds and incubated at room temperature for 5-10 minutes. The mixture of the serum and lysis buffer was transferred to a spin column in a collection tube and centrifuged at 10,000 $\mathrm{g}$ for 60 seconds, after which the collection tube with the flow through was discarded and the spin column transferred to a new collection tube. This was followed by adding $200 \mu \mathrm{l}$ of prewashed buffer to the spin column and centrifuged at $10,000 \mathrm{~g}$ for 60 seconds, after which $500 \mu \mathrm{l}$ of genomic DNA washed buffer was added to the spin column and centrifuged at 10,000 $\mathrm{g}$ for 60 seconds. The DNA was eluted by transferring the spin column into a new $1.5 \mathrm{ml}$ Eppendorf tube and $50 \mu \mathrm{l}$ of elution buffer was added to the spin column and incubated at room temperature. The eluted DNA in the Eppendorf tube was stored at $-20^{\circ} \mathrm{C}$ until used later.

\section{Polymerase Chain Reaction}

Two sets of species-specific primer sets (Table 1) were selected based on published data [41]. The sets of primers were optimized with DNA already extracted from serum samples positive for PCV2a and PCV2b obtained from the Research Centre for Animal Health (CReSA), Cerdanyola del Vallès, Spain, which were also used as positive controls.

Polymerase chain reaction amplification was performed according to $[18,41]$ in a $20 \mu \mathrm{l}$ final reaction volume containing the equivalent of $20 \mathrm{ng}$ of genomic DNA, $10 \mathrm{mM}$ Tris- $\mathrm{HCl}, \mathrm{pH} 8.3,1.5 \mathrm{mM} \mathrm{MgCl}_{2}, 50 \mu \mathrm{M} \mathrm{KCl}, 200 \mu \mathrm{M}$ each of dNTPs, $40 \mathrm{ng}$ of each of the primers and 1 unit of Thermusaquaticus DNA polymerase (Bioneer, USA). Both sets of primers were used to perform PCR for each field sample separately, including the positive control samples. The mixtures were placed in a My Cycler (BIORAD, USA) with the following reaction conditions:

Polymerase chain reaction for PCV2a, and PCV2b involved an initial denaturation at $94^{\circ} \mathrm{C}$ for $5 \mathrm{~min}$, followed by 40 cycles at $94^{\circ} \mathrm{C}$ for $15 \mathrm{~s}, 60^{\circ} \mathrm{C}$ for $20 \mathrm{~s}, 72^{\circ} \mathrm{C}$ for $30 \mathrm{~s}$, and a final extension for $10 \mathrm{~min}$ at $72^{\circ} \mathrm{C}$. The PCR reaction products were visualized by electrophoresis on a $1.5 \%$ agarose gel.

Table 1. Primer sets names, sequences and sizes of the expected amplicon

\begin{tabular}{|c|c|c|c|c|}
\hline Primer set & Species & $\begin{array}{c}\text { Sequences } \\
\left(5^{\prime}-3^{\prime}\right)\end{array}$ & Expected band sizes & References \\
\hline \multicolumn{5}{|l|}{ FPCV2ab } \\
\hline \multirow[t]{2}{*}{ RPCV2a } & PCV2a and PCV2e & CAGTTCGTCACCCTTTCCC & $546 \mathrm{bp}$ & (Z h a i et al., 2011) \\
\hline & & GGGGGACCAACAAAATCTC & & \\
\hline \multicolumn{5}{|l|}{ FPCV2ab } \\
\hline \multirow[t]{2}{*}{$\mathrm{RPCV} 2 \mathrm{~b}$} & PCV2b, PCV2c and PCV2d & CAGTTCGTCACCCTTTCCC & $547 \mathrm{bp}$ & (Z h a i et al., 2011) \\
\hline & & GGGCTCAAACCCCCKCWC & & \\
\hline
\end{tabular}




\section{Statistical analysis}

The raw data were entered into a Microsoft Excel spreadsheet and descriptive statistics was used to present the data. The Statistical Package for Social Sciences (SPSS) version 24.0 was used for the data analysis. The prevalence of the infections within age groups, sexes, and farm locations were compared using the Chi-square test. A $\mathrm{P}<0.05$ was considered significant.

\section{RESULTS}

The band sizes of $546 \mathrm{bp}$ and $547 \mathrm{bp}$ corresponding to the expected band sizes of PCV2a and PCV2b respectively, were obtained on the agarose gel after electrophoresis (Fig-

Table 2. Prevalence of PCV2 in naturally infected pigs by PCR in relation to virus genotype

\begin{tabular}{lcc}
\hline Genotype & $\begin{array}{c}\text { No. positive out } \\
\text { of 207 samples }\end{array}$ & $\begin{array}{c}\text { Prevalence } \\
{[\%]}\end{array}$ \\
\hline PCV2a & 5 & 2.4 \\
PCV2b & 11 & 5.3 \\
$\begin{array}{l}\text { Concurrent PCV2a } \\
\text { and PCV2b }\end{array}$ & 2 & 1.0 \\
\hline Total No. positive & $\mathbf{1 8}$ & $\mathbf{8 . 7}$ \\
\hline
\end{tabular}

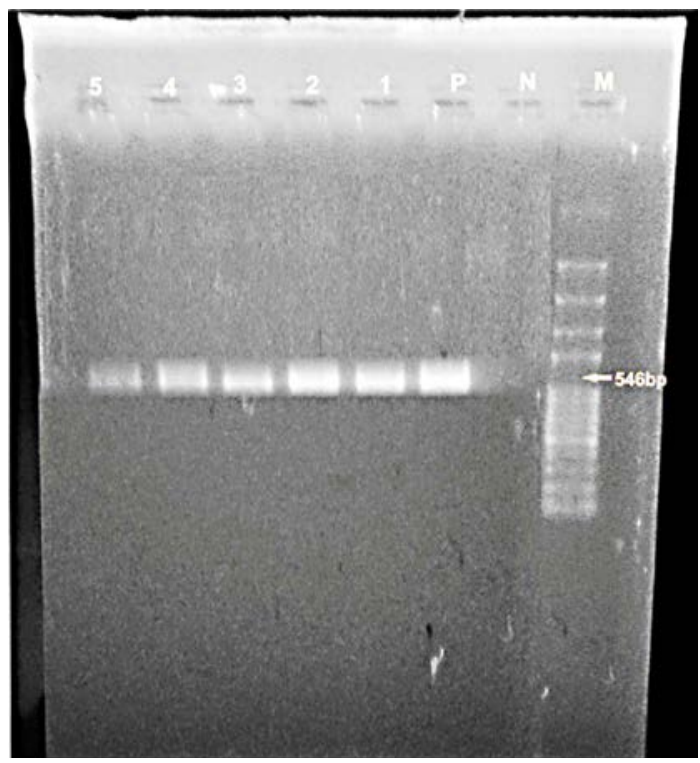

Fig. 1. Agarose gel with the products of PCR amplification of genotype PCV2a from serum samples

Lane $\mathrm{M}-$ Molecular weight standards (100 bp ladder); Lane P-Positive control; Lane $\mathrm{N}-$ Negative control; Lanes $1-5$ are positive field samples ures 1 and 2). The prevalence of PCV2 in naturally infected pigs by the PCR in relation to virus genotype is presented in Table 2. The viral DNAs were detected in $8.7 \%$ of all of the samples. The prevalence of the PCV2 in relation to the pig age group, sex and geographic area are presented in Table 3. There were no significant $(\mathrm{P}>0.05)$ differences in the prevalence of PCV2 among the pig age groups. There was also, no significant $(\mathrm{P}>0.05)$ differences in the prevalence of PCV2 between the sexes. There was a significant $(\mathrm{P}<0.05)$ difference in the prevalence of PCV2 between the high-density and low-density areas. The farmer's opinions on the presence of clinical signs associated with the PCVADs on their farms were said to include: runting, high piglet mortality, late term abortion, still birth and anoestrous in gilts and sows (Table 5). The piglets and growers sampled were observed to show slow growth and emaciation (Figure 3).

\section{DISCUSSION}

A previous study on the prevalence of PCV2 conducted in Ibadan, Nigeria recorded a prevalence of $1.4 \%$, based on screening for IgG antibodies against PCV2 [3]. Hence, our study in Abeokuta complements the previous study and provides information on the detection and the prevalence of PCV2 viral DNA, which indicates that both PC-

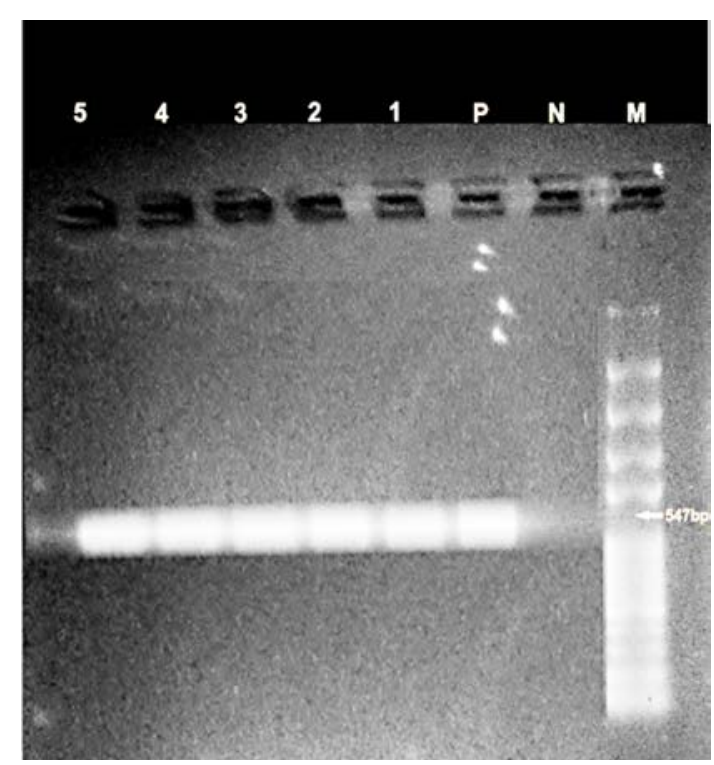

Fig. 2. Agarose gel with the products of PCR amplification of genotype PCV2b from serum samples

Lane M-Molecular weight standards (100 bp ladder); Lane P-Positive control; Lane $\mathrm{N}-\mathrm{Negative}$ control; Lanes $1-5$ are positive field samples 
Table 3. Prevalence of PCV2 in relation to pig age group, sex and geographic area

\begin{tabular}{|c|c|c|c|c|c|}
\hline & $\begin{array}{l}\text { Number } \\
\text { sampled }\end{array}$ & $\begin{array}{l}\text { Number posi- } \\
\text { tive for PCV2 }\end{array}$ & $\begin{array}{c}\text { Prevalence } \\
{[\%]}\end{array}$ & $P$ value & Sign. \\
\hline \multicolumn{6}{|c|}{ Age group } \\
\hline Piglets (0-12 weeks) & 74 & 6 & 8.1 & & \\
\hline Growers (13-24 weeks) & 62 & 5 & 8.1 & & \\
\hline Adults (> 24 weeks) & 71 & 7 & 9.9 & & \\
\hline Total & 207 & 18 & 8.7 & 0.184 & 0.912 \\
\hline \multicolumn{6}{|c|}{ Sex } \\
\hline Male & 85 & 6 & 9.4 & & \\
\hline Female & 122 & 12 & 9.0 & & \\
\hline Total & 207 & 18 & 8.7 & 0.612 & 0.434 \\
\hline \multicolumn{6}{|c|}{ Geographic area } \\
\hline aHigh density areas & 106 & 14 & 13.2 & & \\
\hline bLow density areas & 101 & 4 & 4.0 & & \\
\hline Total & 207 & 18 & 8.7 & 5.57 & $0.018 *$ \\
\hline
\end{tabular}

aHigh density area (Abeokuta North \& Abeokuta South LGAs), $\mathrm{P}<0.05$; bLow density areas (Obafemi-Owode \& Odeda LGAs); ${ }^{*}$-significant

Table 4. Farmers' opinin on the presence of clinical signs associated with PCVAD on their farms

\begin{tabular}{lcc}
\hline $\begin{array}{c}\text { Clinical signs } \\
\text { of PCVAD }\end{array}$ & $\begin{array}{c}\text { Number of farmers } \\
\text { With problems }\end{array}$ & $\begin{array}{c}\text { Percentage [\%] } \\
\text { of all (12) farms }\end{array}$ \\
\hline Runting & 11 & 91.7 \\
High piglet mortality & 10 & 83.3 \\
Late term abortion & 6 & 50.0 \\
Stillbirth & 6 & 50.0 \\
Anoestrus in gilts/sow & 5 & 41.7 \\
\hline
\end{tabular}

V2a and PCV2b are present in pigs in Nigeria. Our study revealed an overall prevalence of $8.7 \%$ for PCV2 DNA in the serum of pigs by the PCR method. This is comparable to the prevalence of PCV2 DNA reported for Korea and USA [5]. Higher PCV2 prevalence has also been reported for South Africa [2], Uganda [39], Slovakia [11], Colombia [32], Japan and the UK [5]. Also, much higher prevalences has been found in Uganda [21] Mozambique [23] and in Taiwan [7] by the PCR.

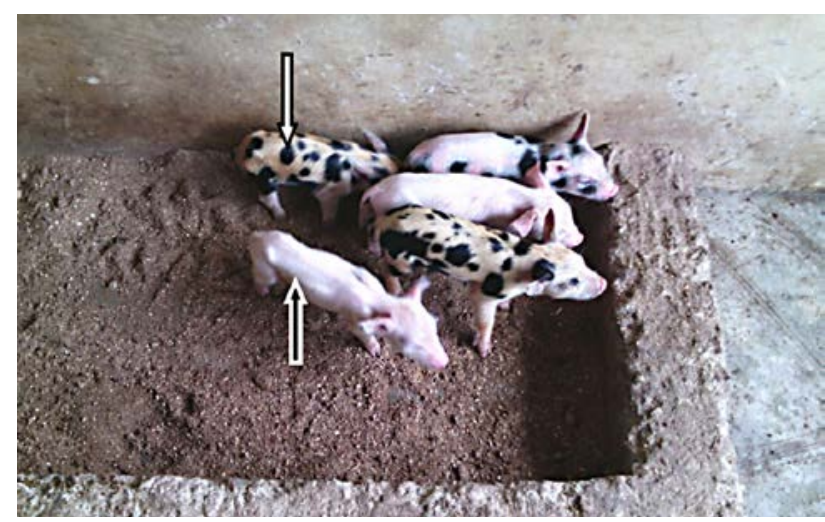

Fig. 3. Sick piglets in one of the sampled farms showing growth retardation and emaciation indicated by downward and upward arrows respectively

Many factors could be responsible for the variations reported in the prevalence across countries, such as the period of sample collection. Studies have revealed that samples collected during disease outbreaks, or thereafter gave a higher prevalence than during the periods of no disease outbreak. In Taiwan, a prevalence of $50.0 \%$ for PCV2 DNA was recorded during the first PCV2 disease outbreak [7]. Thereafter, a much higher prevalence of PCV2 infection in pigs and pig herds $(68.8 \%)$ and $(92 \%)$, respectively were 
observed [8]. The samples employed in this study were collected during periods of no report of any disease outbreak. The absence of an overt disease outbreak may thus explain the low prevalence obtained in this work. Another possible reason for variation in the prevalence is the production group of pigs the study focused on. Our study cut across all production groups of pigs. On the contrary, a study that focused on grower/finisher group in the USA reported a PCV2 high prevalence of over $82.0 \%$ [31]. This suggests that focusing on a particular production system may influence the disease prevalence.

The choice of the sets of primers used in this study was selected by the possibility of detecting other PCV2 genotypes and multiple strain of co-infections. However, attempts to obtain positive DNA samples that would serve as positive controls for the other genotypes were not successful; therefore, this work was focused on detecting only PCV2a and PCV2b. This can however, be confirmed by sequencing and phylogenetic analysis, which, were not included in the objective of our study. Thus, our present study has provided a good foundation for further studies on the molecular characterization of PCV2 in Nigeria. The higher prevalence of PCV2b than PCV2a recorded could be due to a genotypic switch from PCV2a to PCV2b overtime. This is supported by other published reports $[9,10$, 13, 30]. The concurrent infection of PCV2a and PCV2b obtained is an indication that more than one genotype can possibly co-infect the same pig under natural infection. This is also consistent with some earlier reports [18, 41].

Our studies revealed that the pig farmers were of the opinion that runting, high piglet mortality, late term abortion, still birth and anoestrous in gilts and sows, which are problems associated with PCVAD, were present in their farms and are also the most common factors limiting the productivity of their pigs. Out of 136 growers studied, $52.9 \%$ were runted while $36.8 \%$ were emaciated. All of the three farms examined in Abeokuta South LGA were positive for PCV2 infection, whereas two farms out of three examined in each of the other three LGAs namely; Abeokuta North, Obafemi-Owode and Odeda were positive for PCV2 infections. It was observed that the three farms where PCV2 infection was not detected had a reasonable level of farm management and biosecurity measures in place. They had foot dips containing disinfectants at the farm entrance, restricted movement of people were practiced, and work- ers wore protective clothing, boots, and gloves during the farm operations. Isolation and quarantine facilities were also available. These farms also practiced the all-in-all-out system and close weight range of piglets on entry to nursing. This may explain why, in contrast to other nine farms, PCV 2 prevalence was $0 \%$ on these three farms. These findings agree with several epidemiological studies, which have shown that management, housing and husbandry factors were strongly related to the risk of developing PCVAD [33]. Rodent control was absent in all the farms thus predisposing to infections, especially in those farms with poor hygiene. This is an issue of concern, as rodents are possible risk factors in the transmission of PCV2 [29].

It was observed in our study, that adult pigs (gilts, sows and boars) had a slightly higher rate of infection than the piglets (nursery and weaners), and the growers (growers and finishers). Even though there is variation in clinical forms of the disease across age groups, there was no significant difference between the occurrence of PCV2 infection and age groups in this study. This agrees with an earlier report that compared the amount of PCV2 DNA in PCVAD cases and did not identify any age-related association [36].

The prevalence of PCV2 in males was not significantly higher than in females, therefore suggesting that the infection of PCV2 was not influenced by sex. The higher prevalence in Abeokuta South LGA and Abeokuta North LGA than Obafemi-Owode and Odeda LGAs may be due to the higher stocking density of pigs due to space constraints in the urban areas. In addition, most of the pig farms in the high-density areas were in close proximity to each other. Obafemi-Owode and Odeda LGAs that are more sparsely populated, had much lower prevalences. The pig farms in these LGAs were located far away from residential areas and from each other, thereby possibly reducing the risk of PCV2 transmission in these areas. The breed prevalence of PCV2 infection was not studied because all of the pigs sampled were crosses of various breeds.

Although there were no pigs with a definitive diagnosis of PCVADs in this study, four on-farm observations suggested that some farms might have had an outbreak of the disease at some point in time: firstly, weak management practices including inadequate housing facilities and biosecurity measures; secondly, three farms had a recent history of unusually high rates of piglet mortality, infertility, abortion and still births, and large numbers of runts in the 
piglet and grower groups; thirdly, the owner of farm 6 reported that the pigs on the farm did not respond to mass treatment, following a presumptive diagnosis of trypanosomiasis, a disease with similar clinical signs as PCVADs in pigs; and fourthly, both single and mixed infections of PCV2 DNAs were detected in both apparently healthy and the sick pigs on the farms. The scope of our work did not cover the diagnosis of PCVADs. In light of the findings in this study however, such investigations are required as PCVADs may be a differential diagnosis of trypanosmiasis in pigs in the study areas.

\section{CONCLUSIONS}

This work reports on the detection of PCV2 DNA in serum samples of pig populations in Abeokuta, Nigeria, even though the clinical disease has not been diagnosed in the country. It is therefore recommended that large-scale epidemiological studies covering all geographical regions be carried out to diagnose and determine the overall prevalence of PCV2 and PCV2 genotypes in the country by sequencing and phylogenetic analysis.

\section{ACKNOWLEDGEMENTS}

We would like to acknowledge and express our gratitude for the provision of PCV2a and PCV2b DNA positive controls used in this work by Dr. Joaquim Segales and Dr. Marina Sibila of the Centre for Animal Health Research (CRESA), Cerdanyola del Vallès Spain, and also for sharing information on the primers by Dr. Zhai Shao-Lun of Department of Swine Infectious Diseases, Shanghai Veterinary Research Institute, Chinese Academy of Agricultural Sciences, Shanghai, China.

\section{REFERENCES}

1. Afolabi, K. O., Iweriebor, B. C., Okoh, A. I., Obi, L. C., 2017a: Global status of porcine circovirus type 2 and its associated diseases in Sub-Saharean Africa. Adv. Virol., 6807964. DOI: $10.1155 / 2017 / 6807964$.

2. Afolabi, K. O., Iweriebor, B. C., Okoh, A. I., Obi, L. C., 2017b: Molecular detection of porcine circovirus type 2 in swine herds of Eastern Cape Province South Africa. BMC Microbiol., 17, 212. DOI: 10.1186/s12866-017-1121-4.

3. Aiki-Raji, C. O., Adebiyi, A. I., Oluwayelu, D. O., 2018: A slaughterhouse survey for porcine circovirus type 2 in commercial pigs in Ibadan, southwest Nigeria. Folia Veterinaria, 62, 2, 30-34. DOI: 10.2478/fv-2018-0014.

4. Allan, G. M., Krakowka, S., Ellis, J., Charreyre, C., 2012: Discovery and evolving history of two genetically related but phenotypically different viruses, porcine circoviruses 1 and 2. Virus Res., 164, 1-2, 4-9. DOI: 10.1016/j.virusres. 2011.09.013.

5. Allan, G. M., Phenix, K. V., Todd, D., McNulty, M. S., 1994: Some biological and physicochemical properties of porcine circovirus. Zentralbl. Veterinarmed., B41, 1, 17-26.

6. Anonymous, Abeokuta Local Government Areas. (Assessed online, October 2016) from http://www.en.wikipedia. org.

7. Chen, S. P., Weng, Y. J., Tsai, C. P., Chang, W. F., Li, N. J., Tsai, C. E., et al., 2001: Case report: Identification of pathogenic porcine circovirus in pigs with post-weaning multisystemic wasting syndrome in Taiwan. J. Chin. Soc. Vet. Sci., 27, $251-255$

8. Chiou, M. T., Su, P. C., Chuang, M. S., Lin, C. N., 2004: Porcine circovirus type 2 infection status sick or moribund pigs in Taiwan. Taiwan Vet. J., 30, 2, 163-168.

9. Chiou, M., Lin, Chao-Nan., Yang, C., Su, G., Lin, et al., 2012: Genotypic change and phylogenetic analysis of porcine circovirus type 2 in Taiwanese pig herds. J. Vet. Med. Sci., 74, 10, 1303-1310. DOI: 10.1292/jvms.12-0044.

10. Cortey, M., Pileri, E., Sibila, M., Pujols, J., Balasch, M., Plana, J., et al., 2011: Genotypic shift of porcine circovirus type 2 from PCV-2a to PCV-2b in Spain from 1985 to 2008. Vet. J., 187, 3, 363-368. DOI: 10.1016/j.tvjl.2009.12.023.

11. Csank, T., Pistl, J., Polláková, J., Holoda, E., Harvan, M., 2011: Prevalence of porcine circovirus 2 infection in pig population in Slovakia. Acta Virol., 55, 3, 267-271.

12. Drew, T. W., Grierson, S. S., King, D. P., Hicks, D., Done, S., Neser, J. A., et al., 2004: Genetic similarity between porcine circovirus type 2 isolated from the first reported case of PMWS in South Africa and North American isolates. Vet. Rec., 155, 5, 149-51.

13. Dupont, K., Nielsen, E. O., Baekbo, P., Larsen, L. E., 2008: Genomic analysis of PCV2 isolates from Danish archives and a current PMWS case-control study supports a shift in genotypes with time. Vet. Microbiol., 128, 1-2, 56-64. DOI: 10.1016/j.vetmic.2007.09.016. 
14. Franzo, G., Cortey, M., Segalés, J., Hughes, J., Drigo, M., 2016: Phylodynamic analysis of porcine circovirus type 2 reveals global waves of emerging genotypes and the circulation of recombinant forms. Mol. Phylogenet. Evol., 100, 269-280. DOI: 10.1016/j. ympev.2016.04.028.

15. Hardge, T., Gaumann, H., Hasberg, W., Lange, S., 2003: The economic impact of PMWS in the nursery-review of a successful control program. In Proceedings of the 4th International Symposium on Emerging and Re-emerging Pig Diseases, Rome, Italy, June 29-July 2, 203-204.

16. Harmon, K. M., Gauger, P. C., Zhang, J., Piñeyro, P. E., Dunn, D. D., Chriswell, A., 2015: Whole-genome sequences of novel porcine circovirus type 2 viruses detected in swine from Mexico and the United States. Genome Announc., 3, 6, e01315-15. DOI:10.1128/genomeA.01315-15.

17. Harms, P. A., Halbur, P. G., Sorden, S. D., 2002: Three cases of porcine respiratory disease complex associated with porcine circovirus type 2 infection. J. Swine Health Prod., 10, 1, 27-30.

18. Hesse, R., Kerrigan, M., Rowland, R., 2008: Evidence for recombination between PCV2a and PCV2b in the field. Virus Res., 132, 201-207. DOI: 10.1016/j.virusres.2007.10.013.

19. Hines, R. K., Lukert, P. D., 1994: Porcine circovirus as a cause of congenital tremors in newborn pigs. Proc. Am. Assoc. Swine Pract., 25, 344-345.

20. Horlen K. P., Schneider, P., Anderson, J., Nietfeld, J., Henry, J., Tokach, L. M., et al., 2007: A cluster of farms experiencing severe porcine circovirus associated disease: Clinical features and association with the PCV2b genotype. J. Swine Health Prod., 15, 270-278.

21. Jonsson, L., 2013: Emerging infectious diseases: using PCV2 as a model of disease transmission dynamics at the livestockwildlife interface in Uganda. Retrieved, Oct. 25, 2018, from https://stud.epsilon.slu.se/5278/7/jonsson_1_130130.pdf.

22. Kim, H. B., Lyoo, K. S., Joo, H. S., 2009: Efficacy of different disinfectants in vitro against porcine circovirus type 2. Vet. Rec., 164, 599-600.

23. Laisse, C., Souza, C., Pereira, P., De Lorenzo, C., Bianchi, M., Mapaco, L., et al., 2018: Detection and phylogenetic characterization of porcine circovirus 2 from pigs in Mozambique. J. Vet. Diag. Invest., 30, 342-347. DOI: 10.1177/ 1040638718769266.

24. Liu, Q., Tikoo, S. K., Babiuk, 1. A., 2001: Nuclear localization of the ORF2 protein encoded by porcine circovirus type 2. Virol., 285, 1, 91-99, DOI: 10.1006/viro.2001.0922.

25. Madec, F., Eveno, E., Morvan, P., Hamon, L., Morvan, H.,
Albina, E., et al., 1999: La maladie de l'amaigrissement du porcelet (MAP) en France 1-Aspects descriptifs, impact en élevage. (Porcine wasting disease (PWD) in France: 1-Description of the disease and impact in affected herds). J. Rech. Porc. Fr., 31, 347-354.

26. McIntosh, K. A., Harding, J. C., Parker, S., Krakowka, S., Allan, G., Ellis, J. A., 2008: Quantitative polymerase chain reaction for Porcine circovirus-2 in swine faeces in a Porcine circovirus disease-affected commercial herd and a non-affected commercial herd. Can. Vet. J., 49, 12, 1189-1194.

27. Meehan, B. M., Creelan, J. L., McNulty, M. S., Todd, D., 1997: Sequence of porcine 1 circovirus DNA: affinities with plant circoviruses. J. Gen. Virol., 78, 1, 221-227, DOI: 10. 1099/0022-1317-78-1-221.

28. Ojok, L., Okuni, J. B., Hohloch, C., Hecht, W., Reinacher, M., 2013: Detection and characterisation of porcine circovirus 2 from Ugandan pigs. Ind. J. Vet. Path., 37, 1, 77-80.

29. Pinheiro, A., Bulos, L., Onofre, T., Gabardo, M., Carvalho, O., Fausto, M., et al., 2012: Verification of natural infection of peridomestic rodents by PCV2 on commercial swine farms. Res. Vet. Sci., 94, 3, 764-768. DOI: 10.1016/j. rvsc.2012.10.006.

30. Prpić, J., Keros, T., Bedeković, T., Brnić, D., Cvetnić, Z., Roić, B., et al., 2014: Phylogenetic comparison of porcine circovirus type 2 (PCV2) and porcine reproductive respiratory syndrome virus (PRRSV) strains detected in domestic pigs until 2008 and in 2012 in Croatia. Ir. Vet. J., 67, 1, 9. DOI: 10. 1186/2046-0481-67-9.

31. Puvanendirana, S., Stone, S., Yua, W., Johnson, C. R., Abrahantea, J., Jimeneza, L. G., et al., 2011: Absence of porcine circovirus type 1 (PCV1) and high prevalence of PCV 2 exposure and infection in swine finisher herds. Virus Res., 157, 92-98.

32. Rincón, M. M., Ramirez-Nieto, G. C., Vera, J. J., Correa, J. J., Mogollón-Galvis, J. D., 2014: Detection and molecular characterization of porcine circovirus type 2 from piglets with porcine circovirus associated diseases in Colombia. J. Virol., 11, 1, 143.

33. Segalés, J., 2012: Porcine circovirus type 2 (PCV2) infections: clinical signs, pathology and laboratory diagnosis. Virus Res., 164, 1-2, 10-19. DOI: 10.1016/j.virusres.2011.10.007.

34. Segalés, J., Allan, G. M., Domingo, M., 2005: Porcine circovirus diseases, Anim. Health Res. Rev., 6, 2, 119-142.

35. Segalés, J., Domingo, M., 2002: Postweaning multisystemic wasting syndrome (PMWS) in pigs. A review. Vet. Q., 24, 3, 109-124. DOI: 10.1080/01652176.2002.9695132. 
36. Shen, H., Halbur, P. G., Opriessnig, T., 2012: Prevalence and phylogenetic analysis of the current porcine circovirus 2 genotypes after implementation of widespread vaccination programmes in the USA. J. Gen. Virol., 93, 1345-1355. DOI: 10.1099/vir.0.039552-0.

37. Stokes, A. M., Willer, R. D., Zaleski, H. M., 2010: Biosecurity for Swine Producers. College of Tropical Agriculture and Human Resources Livestock Management. University of Hawaii, USA. Retrieved June 28, 2017, from http://www.ctahr. hawaii.edu.

38. West, K. H., Bystrom, J. M., Wojnarowicz, C., Shantz, N., Jacobson, M., Allan, G. M., et al., 1999: Myocarditis and abortion associated with intrauterine infection of sows with porcine circovirus 2. J. Vet. Diagn. Invest., 11, 6, 530-532. DOI: $10.1177 / 104063879901100608$.
39. Wilfred, E., Mutebi, F., Mwiine, F. N., James, O. A., Lonzy, O., 2018: Porcine circovirus type 2-Systemic disease on pig farms and associated knowledge of key players in the pig industry in central Uganda. Int. J. Vet. Sci. \& Med., 6, 178-185. DOI: 10.1016/j.ijvsm.2018.08.004.

40. Xiao, C. T., Halbur, P. G., Opriessnig, T., 2015: Global molecular genetic analysis of porcine circovirus type 2 (PCV2) sequences confirms the presence of four main PCV2 genotypes and reveals a rapid increase of PCV2d. J. Gen. Virol., 96, 1830-1841. DOI: 10.1099/vir.0.000100.

41. Zhai, S., Chen, S., Wei, Z., Zhang, J., Huang, L., Lin, T., et al., 2011: Co-existence of multiple strains of porcine circovirus type 2 in the same pig from China. J. Virol., 8, 517. DOI: $10.1186 / 1743-422 X-8-517$.

Received February 18, 2020

Accepted April 14, 2020 